$\begin{array}{ll} & \text { Etnográfica } \\ \text { etnográfica } & \text { Revista do Centro em Rede de Investigação em }\end{array}$

Antropologia

vol. 20 (3) | 2016

Vol. 20 (3)

\title{
Social intelligence in chimpanzees: a quest for the origin of human mind
}

Inteligência social nos chimpanzés: em busca das origens da mente humana

\section{Satoshi Hirata}

\section{(2) OpenEdition}

\section{Journals}

Electronic version

URL: https://journals.openedition.org/etnografica/4720

DOI: $10.4000 /$ etnografica. 4720

ISSN: 2182-2891

\section{Publisher}

Centro em Rede de Investigação em Antropologia

\section{Printed version}

Date of publication: 1 October 2016

Number of pages: $645-647$

ISSN: 0873-6561

\section{Electronic reference}

Satoshi Hirata, "Social intelligence in chimpanzees: a quest for the origin of human mind ", Etnográfica

[Online], vol. 20 (3) | 2016, Online since 27 November 2016, connection on 10 February 2022. URL http://journals.openedition.org/etnografica/4720 ; DOI: https://doi.org/10.4000/etnografica.4720

\section{(c) (1) (8)}

Etnográfica is licensed under a Creative Commons Attribution-NonCommercial 4.0 International License. 


\section{Social intelligence in chimpanzees: a quest for the origin of human mind}

\section{Satoshi Hirata}

This paper presents experiments conducted by Cláudia Sousa on the use of "tokens" by chimpanzees at Kyoto's Primate Research Institute, Japan. This research gave us a better understanding of chimpanzee cognition in a social context, informing research into prosociality and cooperation.

KEYWORDS: chimpanzees, social intelligence, cognition, cooperation.

Inteligência social nos chimpanzés: em busca das origens da mente humana - Esta comunicação apresenta experiências conduzidas por Cláudia Sousa no uso de tokens por chimpanzés no Primate Research Institute em Quioto, no Japão. Esta investigação permitiu uma melhor compreensão da cognição dos chimpanzés num contexto social, contribuindo para a investigação sobre prossocialidade e cooperação.

PALAVRAS-CHAVE: chimpanzés, inteligência social, cognição, cooperação.

HIRATA, Satoshi (hirata.satoshi.8z@kyoto-u.ac.jp) - Wildlife Research Center, Kyoto University, Japan.

I HAVE BEEN CONDUCTING RESEARCH ON CHIMPANZEES AND OTHER great apes from a comparative cognitive perspective to better understand the evolutionary origins of human behaviour and cognition. In particular, I have explored social intelligence in chimpanzees, including tactical deception, cooperation, and social learning. Hirata and Sousa (2006) extended the paradigm of the study of the use of tokens in chimpanzees into a social situation. In this experiment, two chimpanzees at the Primate Research Institute of Kyoto University, named Chloe and Pendesa, participated. A coin insertion device was placed in a corner of an experimental booth, and a touch-panel was set up in the same booth at a distance of 5 meters from the coin insertion device. Food dispensers were also placed adjacent to the coin insertion device and the touch panel. A computer controlled the coin insertion device, the touch-panel, and the food dispensers. When a coin was inserted into the coin insertion device, a white circle appeared on the touch-panel. Then if the circle on the monitor was touched by a subject, the two food dispensers at the coin insertion device and the touch-panel both delivered a piece of food into the booth. The two chimpanzees, Chloe and Pendesa, were paired and brought to this experimental situation. Two conditions were prepared for the 
test. The first was a situation where a total of 50 coins were provided on the floor of the experimental booth, thus allowing both of the two chimpanzees to gain access to the coins. The second condition was a situation where a total of 50 coins were put into a bag and this bag was given to Chloe. The result of the first condition was that Pendesa almost always collected all of the coins and inserted them into the coin insertion device. Following that, Chloe went to the touch-panel and touched the white circles on the panel. This sequence of behaviors resulted in both of the two chimpanzees obtaining pieces of the food reward. In the second condition where the coins were selectively given to Chloe, Pendesa requested the coins from Chloe by exhibiting begging gestures. Chloe firstly rejected the request. However, in the latter half of the session, Chloe placed the coins on the floor, Pendesa collected and inserted them into the device, and Chloe touched the panel, and both of them obtained food. After repetition of this condition, Chloe gradually began to actively give the coins to Pendesa. During the total of ten sessions, Chloe showed rejection response to Pendesa's requesting behavior on two occasions in the first session, but this rejection behavior was never observed afterwards. Instead, Chloe passively gave coins to Pendesa, by allowing Pendesa to snatch coins from Chloe's hand, twice in the third session, and once in both the fifth and sixth sessions. Chloe more actively gave coins to Pendesa a total of four times during the last three sessions. After giving the coins, Chloe immediately went to the touch-panel. The results of this experiment show that the chimpanzees could establish a division of labor, by one of the pair taking a certain role and the other taking a different role. Behaviors where items are actively shared between individuals, whether it is a food or non-food object, are rarely seen in wild chimpanzees. The present study allowed us to record the entire process of the emergence of giving behavior, which developed from a passive form of object transfer to a more active form. By creating an experimental situation and manipulating the conditions, we were able to observe the process of the emergence and establishment of giving behaviors, which cannot be observed in the wild. This study was a stepping stone for subsequent studies to investigate prosociality and the understanding of others' situations in chimpanzees at the Primate Research Institute. I have also explored similar lines of research by creating an experimental task to study cooperation, showing that chimpanzees are able to understand and succeed in cooperative tasks. The Machiavellian intelligence hypothesis or social intelligence hypothesis put stress on the social use of intelligence in nonhuman primates' daily social lives, and researchers have accumulated evidence showing that social aspects of intelligence are indeed important for them. Our research findings also support the idea that the chimpanzees, the closest living relatives of humans, have highly sophisticated social skills that are shared with humans. 


\section{REFERENCES}

HIRATA, Satoshi, and Cláudia SOUSA, 2006, "Division of labor in chimpanzees" [in Japanese], in Masaki Tomonaga, Masayuki Tanaka and Tetsuro Matsuzawa (eds.), Cognitive and Behavioral Development in Chimpanzees [in Japanese]. Kyoto, Kyoto University Press, 458-461. 